\title{
Management of adenomyosis in infertile women: comparison between laparotomic resection and administration of aromatase inhibitor (Experience in 55 cases)
}

\author{
Rajuddin and T.Z.Jacoeb
}

\begin{abstract}
Abstrak
Tujuan penelitian ini adalah membandingkan hasil pengobatan adenomiosis dengan reseksi dan pemberian inhibitor aromatase. Kasus adenomiosis dengan infertilitas dikumpulkan selama 3 tahun (Januari 1999 sampai Desember 2001) yang dikonfirmasi dengan USG transvaginal. Kasus dibagi 2 kelompok, masing-masing kelompok I (dengan reseksi per laparotomi) dan kelompok 2 (mendapat inhibitor aromatase anastrozole). Keduanya dinilai tentang gejala klinik, angka kehamilan, dan angka perkambuhan pascaoperasi. Selama 3 tahun telah ditangani 1619 kasus infertilitas, di antaranya 66 (4.07\%) adenomiosis sebanyak 55 kasus dianalisis, terdiri atas 32 kasus kelompok 1 dan 23 kasus kelompok 2. Dari 32 kasus yang menjalani reseksi, hasil histopatologik menunjukkan 30 (93.75\%) adenomiosis dan 2 (6.25\%) mioma uteri. Dalam kelompok 1, 3 kasus hamil, 2 melahirkan bayi hidup, 1 kasus terakhir dengan abortus pada kehamilan 6 minggu. Sebanyak 25 kasus (78.1\%) tidak hamil,4 kasus (12.5\%) mengalami perkambuhan, dan pada 24 kasus (75.35\%) gejala-gejala klinis hilang. Sementara itu, 23 kasus kelompok 2, sebanyak 2 (8.6\%) hamil, masing-masing 1 lahir hidup dan 1 abortus. Sebanyak 14 kasus (59.1\%) gejala klinik hilang. Selama pengobatan 3 bulan dengan inhibitor aromatase terjadi penurunan ukuran lesi antara $7.31 \mathrm{~mm}^{3}$ dan $25.90 \mathrm{~mm}^{3}$ dengan Cl 95\% ( $\left.p<0.001\right)$. Disimpulkan bahwa pengobatan dengan inhibitor aromatase tidak menyembuhkan lesi, hanya mengurangi ukuran lesi adenomiosis. Sebaliknya reseksi dapat menghilangkan lesi walaupun perkambuhan dapat terjadi (12.5\%) sesudah 1 tahun pascaoperasi. (Med J Indones 2006; 15:18-23)
\end{abstract}

\begin{abstract}
The objective of this study was to observe the results of adenomyosis mangement with resection and administration of aromatase inhibitor. Cases of ademyosis in infertile women were collected for three years (January 1999 to December 2001) and the diagnoses were confirmed using transvaginal USG. Cases were grouped into two groups, i.e. group 1 (undergoing laparotomic resection) and group 2 (receiving treatment with aromatase inhibitor of anastrozole). Both groups were evaluated for changes in clinical symptoms, rate of successful pregnancy, and postoperative recurrency rate. During three years as many as 1619 infertility cases were managed, and among which 66 (4.07\%) cases of adenomyosis were diagnosed with transvaginal USG. As many as 55 cases were analyzed, i.e., 32 cases underwent resection and 23 cases received aromatase inhibitor. Of 32 cases of surgical resection, the histopathological results showed $30(93.75 \%)$ cases of adenomyosis and $2(6.25 \%)$ cases of uterus myoma. In the group undergoing resection three cases (9.4\%) were successfully pregnant, i.e., two cases had live birth, one case ended up with 6-week abortion. Moreover, 25 (78.1\%) cases were not pregnant and $4(12.5 \%)$ cases had recurrency, while $24(75.35 \%)$ cases experienced disappearance of symptoms yet not pregnant. On the other hand, of 23 cases in the group receiving aromatase inhibitor 2 (8.6\%) cases were able to be pregnant, one case had live birth and another case ended up with abortion, while 14 (59.1\%) cases had disappearance of symptoms yet not pregnant. During three months of treatment with aromatase inhibitor, a reduction in the lesion size between $7.31 \mathrm{~mm}^{3}$ and $25.90 \mathrm{~mm}^{3}$ were observed with CI 95\% ( $p<0.001$ ). In conclusion, treatment with aromatase inihibitor did not heal lesions, but only reduced the size of adenomyosis lesions. On the other hand, resection could heal lesions, yet recurrency of disease may occur (12.5\%) after one postoperative year. (Med J Indones 2006; 15:18-23)
\end{abstract}

Keywords: adenomyosis, resection, aromatase inhibitor, anastrozole

Adenomyosis is an internal endometriosis growing in the myometrium. The characteristic of this condition is

Division of Reproductive Immunoendocrinology, Department of Obstetrics and Gynecology, Faculty of Medicine University Indonesial Dr Cipto Mangunkusumo General Hospital, Jakarta, Indonesia the progressive penetration of stroma and endometrial gland into the myometrium followed by hyperplasia of smooth muscle and changes in local immune environment. $^{1,2}$ This disease is most frequently found to be the cause of dysmenorrhea, menorrhagia and infertility. The growth of adenomyosis is triggered by the weakness of smooth muscle of the uterus or by the 
presence of increased intrauterine pressure or the combination of both. High estrogen level and change of cellular immunity have been associated with the incidence of adenomyosis. ${ }^{1,2,3}$

The majority of the disease appear at the end of reproductive and perimenopausal period. ${ }^{1}$ Its incidence rate varies according to the modality of examination and identification of cases. Clinically, $10-20 \%^{3}$ of the cases were identified, and histopathologically 20$40 \%{ }^{1,3,4}$ of cases were found. More than $80 \%$ of patients with adenomyosis have abnormal uterus; $50 \%$ are accompanied by uterine myoma, $11 \%$ by endometriosis, and $7 \%$ by endometrial polyp. ${ }^{1,5}$ Postoperative and post-medical treatment recurrence was $33-40.3 \%$.,

The clinical symptoms of this disease vary considerably, and the most frequently found symptom is dysmenorhea $(80 \%)$, in addition to pelvic pain (50\%), infertility (40\%), and menstrual disorder (20\%). Other accompanying symptoms include menorrhagia, dyspaurenia, suprapubic pain, uterus enlargement, mixed disorder, and some cases are not accompanied by complaints. Menorrhagia occurs as a result of increased tissue vascularization, and the uterine muscles cannot contract appropriately because of the presence of tissue mimicking the endometrium in the middle of it. ${ }^{1,5,6,7}$

Until recently controversies on how to perform diagnosis and management of the disease still go on, particularly in women who still want the uterus and/ or want to have child. Diagnosis can only be confirmed histopathologically. In women with sufficient parity and elderly women, treatment of choice for adenomysis which is recommended is total hysterectomy. Surgical intervention is also recommended when the hormonal therapy of 3 months has not yielded satisfactory results. In women of reproductive age accompanied by infertility problems, intervention that should be considered is adenomyosis resection. ${ }^{1,3,8}$

On the other hand, a new medicinal therapy with aromatase inhibitor has begun to be developed with the purpose, among other things, to suppress the formation of exogen estrogen (from fat tisssue to the skin) due to the effect of aromatase activation. By inhibiting aromatase activation directly, $\mathrm{E}_{2}$ serum level in the endometrial tissue will be reduced. ${ }^{8,9}$ It is expected that by this mechanism the growth of endometrial lesion will be inhibited. This paper will generally address the experience in managing adenomyosis in infertile women by way of resection, and medicinal therapy using aromatase inhibitor for patients who refuse to undergo resection.

\section{METHODS}

This study was a retrospective, descriptive and analytic trial performed in infertile women for a period of 3 years (from January 1999 to December 2001). As many as 1619 cases of infertile women were managed and screened at the Fertility and Menoandropause SamMarie Clinic, Jakarta. Clinical data collected from patients' medical records included age, length of infertility, lesion size, complaints and symptoms, anatomic-pathological results, medicinal therapy, and resection intervention. Anatomicpathological data of the resection outcome were reascertained by anatomic-pathologist at Budhi Jaya Maternity and Children Hospital, Jakarta.

For each infertile patient a screening and basic examinations of fertility were performed. Internal genitals, particularly, the uterus was examined with 7.5 MHz Panasonic transvaginal ultrasonography (USG). Diagnosis of adenomyosis was based on the findings of unclearly-defined focal area and decreased or increased echogenecity. The type of case management was classified into two parts, i.e., group I treated with aromatase enzyme inhibitor (anastrozol) and group II undergoing adenomyosis resection through laparotomy.

In the group undergoing resection, pre-surgical patients were injected with $3.6 \mathrm{mg}$ acetate goserelin (Zoladex) subcutaneously for four weeks beforehand. Intervention of adenomyosis resection was performed in the fifth week. Postoperative injection was continued twice for every 4 weeks. In the group of anastrozol, the medication tablet was administered orally at $1 \mathrm{mg}$ daily for 3 months @ 28 tablets. Data collected were processed and analyzed in terms of pregnancy success, disappearance of symptoms, disease recurrence. Statistical test was performed with Chi Square $\left(X^{2}\right)$ and Student-t test with significance degree (p) of 0.05. In the data processing and presentation, mean was presented in standard error (SE) as $\bar{X} \pm \mathrm{SE}$.

\section{RESULTS}

Of 1619 cases of infertile women managed in the early screening, $4.1 \%(66 / 1619)$ of the cases were adenomyosis. As many as $54.6 \%(36 / 66)$ of the cases underwent surgery, consisting of $48.5 \% \quad(32 / 66)$ resection cases and $8.1 \%(4 / 66)$ hysterectomy cases. The cases undergoing hysterectomy were excluded from analysis. The rest, i.e., 45.5\% (30/66) of the cases were managed medicinally, i.e., $34.9(23 / 66)$ of 
the cases received aromatase inhibitor and $10.6 \%$ (7/66) of the cases received combined progesterone medications. Cases receiving treatment with combined hormones were excluded from analysis. Furthermore, the number of cases analyzed was 55, consisting of 32 resection cases and 23 cases receiving only aromatase inhibitor.

\section{Characteristics of cases}

Distribution of cases on the basis of age characteristics, length of infertility and lesion volume were presented in Table 1. Of 55 cases identified, it is evident that age $(\bar{X} \pm \mathrm{SE})$ is $35.3 \pm 0.7$ years, with the oldest age of 50 years and the youngest age of 28 years. Length of infertility $(\bar{X} \pm$ SE) is $86.9 \pm 8.5$ bulan, with the shortest length of infertility of 9 months and the longest length of infertility of 296 months. The smallest lesion volume is $2.8 \mathrm{~mm}^{3}$ and the largest is $119.4 \mathrm{~mm}^{3},(\bar{X} \pm \mathrm{SE}) 28.9 \pm 3.8 \mathrm{~mm}^{3}$.

Table 1. Characteristics of cases

\begin{tabular}{lcc}
\hline \multicolumn{1}{c}{ Variabel } & $\mathrm{n}$ & $\bar{X} \pm \mathrm{SE}$ \\
\hline Age (year) & 55 & $35.3 \pm 0.7$ \\
Lesion volume $\left(\mathrm{mm}^{3}\right)$ & 55 & $28.9 \pm 3.8$ \\
Length of infertility (bl) & 55 & $86.9 \pm 8.5$ \\
\hline
\end{tabular}

\section{Parity}

In this study, the most frequently found parity was nil (40 cases, $72.7 \%$ ), parity 1 (11 cases, $20.0 \%$ ), followed by parity 2 and 3 as presented in Table 2 .

Table 2. Characteristics of case parity

\begin{tabular}{ccc}
\hline Parity & $\mathrm{N}$ & $\%$ \\
\hline 0 & 40 & 72.7 \\
1 & 11 & 20.0 \\
2 & 1 & 1.8 \\
3 & 3 & 5.5 \\
\hline Total & 53 & 100 \\
\hline
\end{tabular}

\section{Patient's complaints}

The most frequently symptom complained by patients was dysmennorhea (17 cases, 30.9\%), dysmenorrhea and dyschezia (16 cases, 29.1\%). On the other hand, other symptoms were distributed relatively the same as presented in Table 3.
Table 3. Patient's complaints

\begin{tabular}{lrc}
\hline Patient's complaints & $\mathrm{n}$ & $\%$ \\
\hline Dysmenorrhea & 17 & 30.9 \\
Dysmenorrhea and dyschezia & 16 & 29.1 \\
Pelvic pain & 9 & 16.4 \\
Menorrhagia & 7 & 12.7 \\
Dyspareunia & 6 & 10.9 \\
\hline Total & 55 & 100.0 \\
\hline
\end{tabular}

\section{Diagnosis}

Of 55 cases, the histopathological results of 32 cases undergoing surgical resections showed 24 cases (75.0\%) of adenomyosis only and 6 cases $(18.7 \%)$ of mixed adenomyosis and endometrial cyst, the rest were 2 cases $(6.3 \%)$ of uterine myoma (Table 4$)$. On the other hand, in medicinal therapy diagnosis of adenomyosis was confirmed with only transvaginal USG.

Table 4. Preoperative diagnosis i (USG) and postoperative diagnosis (AP)

\begin{tabular}{lcc}
\hline Diagnosis & USG & AP Results \\
\hline $\begin{array}{l}\text { Adenomyosis } \\
\text { Adenomyosis and } \\
\text { endometrial cyst }\end{array}$ & $6(181.3 \%)$ & $24(75.0 \%)$ \\
Uterine myoma & $0(0 \%)$ & $6(18.7 \%)$ \\
\hline Total & $32(100 \%)$ & $2(6.3 \%)$ \\
\hline
\end{tabular}

\section{Results of treatment with surgery}

\section{Pregnancy and symptom disappearance}

Of 32 cases undergoing resection (Table 5), 3 cases $(9.4 \%)$ were able to get pregnant, i.e., two cases had live birth and one case had 6-week abortion. Twentyfive cases $(78.1 \%)$ were not pregnant and 4 cases $(12.5 \%)$ experienced disease recurrence.

Table 5 Pregnancy and symptom disappearance

\begin{tabular}{lcc}
\hline Results & $\mathrm{n}$ & $\%$ \\
\hline Pregnant & & \\
Pregnant and delivers & 2 & 6.3 \\
Pregnant and abortion & 1 & 3.1 \\
Not pregnant & 25 & 78.1 \\
Recurrence & 4 & 12.5 \\
$\quad$ Total & 32 & 100 \\
\hline Symptom remission & & \\
Symptoms disappear & 28 & 87.5 \\
Symptoms remain & 4 & 12.5 \\
$\quad$ Total & 32 & 100 \\
\hline
\end{tabular}




\section{Symptoms disappear}

Of 32 cases undergoing resection, 28 cases $(87.5 \%)$ experienced disapperance of symptoms while 4 cases (12.5\%) had remaining symptoms (Table 5).

\section{Therapy with aromatase inhibitor}

\section{Pregnant}

Twenty-one cases $(91.4 \%)$ were found to be unsuccessfully pregnant, 2 cases $(8.6 \%)$ were successfully pregnant, i.e., one case was pregnant had live birth, and the other ended up in abortion (Table 6).

Table 6. Pregnancy and symptoms remission

\begin{tabular}{lcc}
\hline \multicolumn{1}{c}{ Results } & $\mathrm{n}$ & $\%$ \\
\hline Pregnant & & \\
Pregnant + Delivery & 1 & 4.3 \\
Pregnant + Abortion & 1 & 4.3 \\
Not pregnant & 21 & 91.4 \\
\hline Total & 23 & 100 \\
\hline Symptoms remission & & \\
Symptoms disappear & 14 & 60.9 \\
Symptoms remain & 9 & 39.1 \\
\hline Total & 23 & 100 \\
\hline
\end{tabular}

\section{Symptoms disappear}

After therapy of 3 months as many as 14 cases (60.9) experienced disappearance of symptoms, while 9 cases $(39.1 \%$ ) had remaning symptoms (Table 6).

\section{Relationship between lesion size before and after therapy with aromatase inhibitor}

Before therapy, lesion volume ( $\bar{X} \pm \mathrm{SE}$ ) was $24.5 \pm$ $5.3 \mathrm{~mm}^{3}$ with CI of $95 \%$, and lesion volume decreased from $7.3 \mathrm{~mm}^{3}$ to $25.9 \mathrm{~mm}^{3}$. Mean lesion size before and after therapy was 16.6, and SE 4.5. Based on $\mathrm{t}$ paired test, therapy with aromatase inhibitor for a period of 3 months showed a significance decrease in lesion size $(\mathrm{p}<0.001)$.

\section{Relationship between the type of resection management and Aromatase inhibitor and disappearance of symptoms}

Table 8 shows that the disappearance of symptoms occurs in 14 cases $(60.9 \%)$ of 23 cases receiving medications, and in 28 cases $(87.50 \%)$ of 32 cases undergoing resection. On Chi Square test, it proved that there is a significant relationship between resection and aromatase inhibitor in predicting disappearance of symptoms by $\mathrm{p}<0.05)$.

Table 7. Difference between lesion size before and after therapy with aromatase inhibitor

\begin{tabular}{lccccc}
\hline \multicolumn{1}{c}{ Variable } & $\mathrm{n}$ & $\bar{X} \pm S E$ & CI 95\% & $t$ & $p$ \\
\hline $\begin{array}{l}\text { Lesion volume } \\
\text { before therapy }\end{array}$ & 23 & $24.5 \pm 5.3$ & & & \\
& & & & & \\
$\begin{array}{l}\text { Lesion volume } \\
\text { after therapy }\end{array}$ & 23 & $7.9 \pm 1.5$ & $7.3-25.9$ & 3.71 & 0.001 \\
& & & & &
\end{tabular}

Table 8. Relationship between the type of management and disappearance of symptoms and successful pregnancy

\begin{tabular}{|c|c|c|c|c|}
\hline \multirow[t]{2}{*}{ Variable } & \multicolumn{2}{|c|}{$\begin{array}{c}\text { Type of } \\
\text { management }\end{array}$} & \multirow[t]{2}{*}{ Total } & \multirow[t]{2}{*}{$p$} \\
\hline & $\begin{array}{l}\text { Medica- } \\
\text { tion }\end{array}$ & $\begin{array}{l}\text { Resec- } \\
\text { tion }\end{array}$ & & \\
\hline $\begin{array}{l}\mathrm{n}=55 \\
\text { Symptom recovery }\end{array}$ & & & & \\
\hline Symptoms disappear & $\begin{array}{c}14 \\
(60,9 \%)\end{array}$ & $\begin{array}{c}28 \\
(87.5 \%)\end{array}$ & $\begin{array}{c}42 \\
(76.4 \%)\end{array}$ & 0.48 \\
\hline Symptoms remain & $\begin{array}{c}9 \\
(39,1 \%)\end{array}$ & $\begin{array}{c}4 \\
(12.5 \%)\end{array}$ & $\begin{array}{c}13 \\
(23.6 \%)\end{array}$ & \\
\hline $\begin{array}{l}\mathrm{n}=49 \\
\text { Successfully pregnant }\end{array}$ & & & & 0.79 \\
\hline Pregnant & $\begin{array}{c}2 \\
(11,8 \%)\end{array}$ & $\begin{array}{c}3 \\
(9.4 \%)\end{array}$ & $\begin{array}{c}5 \\
(10.2 \%)\end{array}$ & \\
\hline Not-pregnant & $\begin{array}{c}15 \\
(88,2 \%)\end{array}$ & $\begin{array}{c}29 \\
(90.6 \%)\end{array}$ & $\begin{array}{c}44 \\
(89.8 \%)\end{array}$ & \\
\hline
\end{tabular}

\section{Relationship between the type of resection management and aromatase inhibitor and pregnancy}

It is evident from Table 8 that 2 cases (11.8\%) of 17 cases receiving aromatase inhibitor were pregnant, 3 cases $(9.4 \%)$ were pregnant of 32 cases undergoing resection. Based on Chi Square test, it was found that $\mathrm{p}=0.79$. This means that there is no significant relationship between resection and therapy with aromatase inhibitor in predicting the occurence of pregnancy. In the present study, the number of cases analyzed was 49 of 55 cases, 6 cases were not analyzed because of age above 42 years. 


\section{DISCUSSION}

Clinically, complaints of adenomyosis are similar to those of uterine myoma, including dysmenorrhea, menorrhagia, and uterus elargement. Uterus enlargement in ademyosis generally has diffuse nature, such that the uterus enlarges symetrically with globular structure. ${ }^{1,2}$ In focal type, the enlargement may occur either symetrically or asymetrically and may result in dysmenorrhea. Generally, uterine wall thickens and posterior wall is usually thicker. ${ }^{5}$

Adenomyosis may be encountered as unclearlydefined tumor, known as endometrioma uteri, and is difficult to distinguish it from uterine myoma. The typical microscopic appearance of adenomyosis is the presence of stroma and gland similar to ectopic endometrium in the uterine muscles. ${ }^{1,3,5}$ This endometrium-like gland may follow cyclic changes, and generally it reacts imperfectly toward the effect of steroid hormone of ovarium. Pregnancy will cause the ectopic endometrium-like gland to change as decidua. Muscle tissues around the endometrium-like undergo hypertrophy and hyperplasia with the appearance of non-capsule tumor with blackened spots inside. ${ }^{1,7}$

The characteristics of cases in this study demonstrate that adenomyosis occurs more frequently at the age of 31-35 years with a mean of $35.3 \pm 0.7$ years. The majority of cases $(72.7 \%$ ) had nil parity. This may be due to the fact that the cases studied were infertility patients who had long wanted to have children with mean length of infertility of $86.9 \pm 8.5$ months. As reported by Wang et al ages above 30 years and length of infertilty above 60 months were found in all patients. ${ }^{11}$ In order to confirm diagnosis of adenomyosis with transvaginal USG, it would be best that the diagnosis is based on the appearance of hypoechoic region, asymetrical uterine enlargement, unclearly-defined endometrium and myometrium, and the thickening of endometrium halo. ${ }^{12}$

Previous studies demonstrated that transvaginal ultrasonography was able to assess the mass in the pelvic and to distinguish between ovarian endometriosis and other ovarian masses. ${ }^{10}$

Transvaginal ultrasonography has a sensitivity of $84 \%$ and specificity of $90 \%$ in the ovarian mass. ${ }^{12}$ In this study, 32 cases were diagnosed with adenomyosis using transvaginal USG. The histopathological results after resection showed that 30 cases $(93.7 \%)$ were in accordance with adenomyosis and 2 cases $(6.3 \%)$ with uterine myoma. The uterus that enlarged diffusely did not all prove to be adenomyosis because there were 2 cases whose histopathological results showed the presence of uterine myoma. This showed that uterine myoma may assume the form of either focal or diffuse, just as adenomyosis.

The development and growth of endometrial lesion in pre-menopausal women depend on the estrogen orginating from the ovary and periphery (fat and skin tissues), while in post-menopausal women from peripheral estrogen. The use of aromatase inhibitor will eliminate the appearance of mRNA aromatase in lesion tissue as a result of estrogen disappearance. ${ }^{8,9}$ We hypothesized that the administration of nonspecific steroid aromatase inhibitor (anastrozol) will suppress estrogen biosynthesis such that the growth of adenomyosis will remiss. The appearance of aromatase in the endometrial lesion tissue will disappear after the administration of therapy with aromatase inhibitor of anastrozol. In addition, it is expected that the administration anastrozol will cause direct inhibition of aromatase activity in endometrial tissue. ${ }^{8}$ In the present study, there is a decrease in the volume of adenomyosis lesion between $7.3 \mathrm{~mm}^{3}$ and $25.9 \mathrm{~mm}^{3}$ after three months of therapy with anastrozol. When compared with lesion volume before therapy, it shows a significant remission $(p<0.001)$. This may be due to the effect of aromatase inhibitor in blocking the formation of estrogen in fat and skin tissues such that estrogen is reduced in endometrial tissue. ${ }^{8}$

In this study, pregnancy rate in the resection group was $9.4 \%$, while in group receiving aromatase inhibitor of anastrozol $8.6 \%$ with mean length of therapy of 4.2 months. No significant difference was observed in pregnancy rate between after resection and after the administration of medications. The last pregnancy with miscarriage occurred in 1 case in both groups respectively. This is consistent with the report presented by Luke et al. ${ }^{7}$ that the risk of abortion in adenomyosis women was 4 times as high as that in women without adenomyosis. Postoperative recurrence was $33-40.3 \% .^{6}$ In the present study, a recurrence rate of $12.5 \%$ was found in the resection group after one year.

In terms of complaints, it was said that $35 \%$ of adenomyosis pateints did not experience complaints or were without symptoms, while the rest experienced complaints such as dysmenorrhea, pelvic pain and menorrhagia. ${ }^{7}$ In this study, all patients had complaints, 
i.e., $60 \%$ had dysmenorrhea, $12.7 \%$ menorrhagia, and $27.3 \%$ pelvic pain - dyspaurenia. This may be due to the fact that patients were presented for treament because of complaints and infertility. Dysmenorrhea may be caused by uterus irritability or pseudo-decidual edema around adenomyosis lesion. Inapproriate uterine contractions during menstruation will broaden endometrium surface, resulting in excessive production of prostaglandin, and on the other hand hyperestrogen is considered the cause of menorrhagia. ${ }^{7,8}$

The relatively low rate of symptom remission and pregnancy in the present study may be due to the following factors:

1. Many patients did not present for control on a regular basis such that it is difficult to perform the management of infertility

2. Therapy with anastrozol was relatively of short period such that pregnancy cannot be expected too much.

3. Other therapy, such as ovulation trigger, was not administered.

4. Other causes of infertility have not been completely managed.

5. Patients' age was too old and length of infertility too long.

\section{CONCLUSIONS}

In summary, the preliminary results of therapy with aromatase inhibitor of anastrozol administered orally were an effective method to reduce lesion size and to eliminate lesion. However, it did not heal adenomyosis lesion. Successful pregnancy rate reached $8.6 \%$, such that aromatase inhibitor may serve as an alternative therapy for infertility patients who were not willing to undergo surgical resection. On the other hand, therapy with resection was able to eliminate lesion and successful pregnancy rate reached $9.4 \%$ with recurrence rate of $12.5 \%$. In order to assess the side effect of medication and other effects of aromatase inhibitor of anastrozol on the body, it is necessary perform further study with a greater size of sample.

\section{Acknowledgement}

We would like to thank dr. Mahlil Rubi, M.Kes for this help in conducting the statistical analysis and dr. R.Muharam, SpOG for their invaluable help in this study.

\section{REFERENCES}

1. Kistner's Ryan, Adenomyosis in Gynecology \& Women's Health, $7^{\text {th }}$ ed , Philadelphia: Mosby -Year $1999: 127-9$.

2. Speroff L, Glass RH, Kae NG, Clinical Endocrinology Gynecologic and infertility: Endometriosis. Philadelphia: Lippincott Williems and Wilkins, 1999: 1057-9.

3. Hesla JS,Rock JA Endometriosis in Te Linde's Operative Gynecology $7^{\text {th }}$ ed

4. Philadelphia: Lippincott-Raven 1992:463-93

5. Ben AN, Berriri H, Gara F. Adenomyosis: analysis of 35 cases. Tunis med 2001, 79 (8-9): 447-51.[Medline]

6. Ferenczy A. Pathophysiology of adenomyosis. Hum Reprod Update 1998, 4:312-22.[ Medline]

7. Davis M, Endometriosis, Adenomyosis, and Leiomyosis Medical Library Home Tabl Content. MD Consult.com.

8. Michael L, Maria AA, Andrew T. Adenomyosis: Symptoms, Histology, and Pregnancy Terminations. Obstet Gynecol 2000;95:688-91.

9. Zeitoun K, Bulun SE. Aromatase: a key molecule ini the pathophysiology of endometriosis and a therapeutic target. Fertil Steril 1999;72:961-7.

10. Takayama K, Zaitoun K, Gunby RT, Sasano H , Carr BR, Bulun SE. Treatment of severe postmenopausal endometriosis with an aromatase inhibitor. Fertil Steril 1998: 69: 709-13.

11. Eskanazi B, Wamer M, Bonsignore L, Olive D, Samuels S, Vercellini P. Validation study of nonsurgical diagnosis of endometriosis. Fertil Steril 2001; 76: 929-35

12. Wang PH, Yang TS, Lee WL, Chao HT, Chang SP, Yuan CC. Treatment of infertile women with adenomyosis with a conservative microsurgical technique and a gonadotropinreleasing hormone agonist. Fertil Steril 2000; 73: 1061-2.

13. Botsis D. Adenomiosis and leiomyoma; Differential diagnosis with transvaginal sonography. J Clin Ultrasound 1998; 26: 21-5. 